\title{
Photosynthetic Based Technology for the Bioremediation of Domestic Sewage Water Using Anoxygenic Bacteria
}

\author{
Katherin Sylvia, Ashutosh Kumar, Fc Lalsiamliani, Mayank Nagotra, Malaiyarasa Pandian* \\ Department of Microbiology, Indian Academy Degree College-Autonomous, Bengaluru
}

\begin{abstract}
Bioremediation employs the use of naturally occurring organisms to break down hazardous substances into less toxic or non-toxic substances. The conventional treatment method ofdomestic sewage water is expensive and generates waste sludge that requires further handling and the problem of disposal of sludge into the environment is risky as it has a high potential to pollute the environment. The development of a simple and cost effective process allows the implementation of bioremediation in a safer and effortless manner. Therefore in this investigation microbiological and chemical analyses were very useful to suggest the best ways to improve bioremediation limits in domestic sewage water. In the study indigenous anoxygenic phototrophic bacteria were isolated from domestic sewage water to treat domestic sewage waste water, to develop a costeffective process for bioremediation. Domestic sewage water was analyzed for different physico-chemical parameters such as $\mathrm{pH}$, Temperature, TDS, TSS, TS, $\mathrm{DO}, \mathrm{BOD}, \mathrm{COD}$, total sulphate and chlorides using bio inoculants of anoxygenic phototrophic bacteria isolated and domestic sewage water in an suitable light, $\mathrm{pH}$ and temperature conditions. The results showed that among the 3 anoxygenic phototrophic bacteria isolated; isolate RP2 (Rhodopseudomonas palustris) could grow well at $\mathrm{pH}$ 8, temperature $30^{\circ} \mathrm{C}$ and also reduce more pollutant parameters in domestic sewage water during bioremediation in the period of four consecutive weeks at the rate of $80 \%$.
\end{abstract}

Keywords Anoxygenic Phototrophic Bacteria, Bioremediation, Pollutant, Rhodopseudomonas palustris, Sewage water

\section{Introduction}

Water is one of the most important elements on earth. All plants and animals must have water to survive. Due to industrialization and urbanization, it is becoming more polluted and risk ofthis polluted water consumption and its sanitation problem is increasing day to day in most of the developing countries. Hence it has become an essential need for today's environment to protect water from getting polluted or to develop cost effective remedial method for its protection. Generally, the wastewater discharged from domestic premises like residences, institutions and commercial establishments is termed as "Sewage/Community wastewater". It comprises of $99.9 \%$ water and $0.1 \%$ solids and is organic because it consists of carbon compounds like human waste, paper, vegetable matter etc. The current piped sewerage systems do not treat sewage but merely transport it away. They are toxic and extremely pollutethe rivers and lakes where they are dumped. While in India only 33 per cent of houses are connected to sewer systems, only around 38 per cent use septic tanks. These septic tanks do not treat waste and have to be emptied periodically. The report points out that entrepreneurs who service septic tanks, pump out the sludge from the tanks and empty it into drains, fields, just about anywhere. Many domestic wastes are organic in composition and can be treated physico-chemically and/or by microorganisms (1). In green technology, both algae and bacteria have shown to degrade organic and inorganic compounds. Almost completely and their degraded product also does not show any estrogenicactivity. The biodegradability by anaerobic treatment is strongly dependent on the characteristics of the wastewater (2). Further the biodegradation is also influenced by numerous chemical factors, such as structural properties and environmental factors. Integrated algal systems can be used for wastewater treatment and bioremediation to capture carbon, nitrogen and phosphorus from specialty industrial, municipal and agriculture wastes.

Anoxygenic photosynthetic bacteria (APB) are one of the general terms for prokaryotes holding the original photosynthetic system, which had large variety and wide distribution in the environment (3). The traces of which are often observed in the paddy fields, lakes, rivers, oceans, activated sludge and soil (4). Their photosynthesis depends on the external electron donor, such as sulphide, molecular hydrogen or organic substances. APB have become famous for wastewater purification in recent times, since there are two flexible metabolic pathways for them, i.e. the respiratory and the fermentative pathways which enable them to adapt to varied environmental condition. Experimental data also proved that some APB species have high toxicity resistant level and can survive in toxic ridden wastewater whereby it utilizes the toxic substances as carbon source for growth and reproduction (5). So far, photosynthetic based technology for the bioremediation of domestic sewage water using anoxygenic bacteria has not been studied with certain physical parameters. Hence, the 
present study was conductedto evaluate the potential of anoxygenic phototrophic bacterial isolates on domestic sewage water.

\section{Materials and Methods}

\section{Collection of sample}

Domestic Sewage water (DSW) samples were collected from Bangalore Sewage channel $\left(13^{\circ} 02^{\prime} 34.8^{\prime \prime} \mathrm{N}\right.$ $77^{\circ} 38^{\prime} 42.2^{\prime \prime} \mathrm{E}$ ) by using wide mouthed sterilized $1000 \mathrm{ml}$ plastic bottles and BOD bottles without causing bubbles and transported to the laboratory with the help of coolant pack within one hour. The samples were stored for furtherstudies.

\section{Physicochemical analysis}

Physicochemical analysis of domestic sewage water discharge was undertaken before starting bioremediation studies. The physicochemical parameters like, $\mathrm{pH}$, Temperature, Biological oxygen demand (BOD), Chemical oxygen demand (COD), Total suspended solids (TSS), Total Dissolved solids, Total solids, Sulphate and Chloride were analyzed by following standard manual (6).

\section{Isolation of Anoxygenic phototrophic bacteria}

The collected domestic sewage water sample was used as inoculums, and pour plated with $20 \mathrm{ml}$ of $\mathrm{G} 5$ agar medium at $45^{\circ} \mathrm{C}$. The medium was allowed to solidify. The plates were then over laid with molten paraffin wax $\left(60^{\circ} \mathrm{C}\right)$, which solidified upon layering. The plates were rotated gently in a circular motion while pouring the wax in order to spread it evenly over the agar surface (7).

The plates were kept open for a period of $10 \mathrm{~min}$ after pouring the paraffin wax in order to radiate the heat of the wax before closing the lid and incubated at a temperature of $30 \pm 2^{\circ} \mathrm{C}$ with the agar side of the plate exposed to a light intensity of 2400 lux, for 12- 15 days. Agar plate cultures were sealed in gas pack jars. At the end of the incubation period, the brownish red- pink Coloured colonies were isolated and purified by repeated streaking on fresh G5 agar medium. The isolated organisms were coined with initials and maintained at $4^{\circ} \mathrm{C}$ on slants of $\mathrm{G} 5$ agar medium.

\section{Maintenance and characterization of APB isolates}

Isolates of APB were maintained as agar stabs or as broth cultures. Stabs were prepared using modified G5 medium with $2 \%(w / v)$ agar as solidifying agent, filled to $3 / 4$ volumes of $5 \mathrm{ml}$ capacity screw cap test tubes. The culture was stabbed into the agar deeps and incubated at 2,400 lux and $30 \pm 2^{\circ} \mathrm{C}$. After 4-6 days of growth, the stab cultures were preserved under refrigeration at $4^{\circ} \mathrm{C}$ until further use. The purified APB isolates were characterized andidentified (8).

\section{Growth at different temperatures and $\mathrm{pH}$}

Growth of the isolates at different temperatures viz., 25,30 and $35^{\circ} \mathrm{C}$ in 7 pHand also at different $\mathrm{pH}$ viz., $6,7,8$ and 9 was monitored by incubating the inoculated cultures in G5 growth medium under phototrophic conditions at 2400 lux.

\section{Bioremediation studies}

Bioremediation of domestic sewage water discharge using anoxygenic phototrophic bacteria (APB) was done by growing the isolates in BOD bottle with domestic sewage water discharge supplemented with G5 medium. The domestic sewage water discharge with a $\mathrm{pH}$ correction of 7.5 was supplemented with optimized APB isolates in their exponential phase of growth with a cell density of $0.3 \mathrm{OD}$ at $660 \mathrm{~nm}$ with three different lots (Control- DSW + G5 Medium + Distilled water; L1$\mathrm{DSW}+\mathrm{G} 5$ Medium + RP1; L2- DSW + G5 Medium + RP2). The BOD bottles were maintained at $30 \pm 2^{\circ} \mathrm{C}$ in a temperature-controlled environment and illumination was provided by placing the glass stopper bottles in an illuminated tissue culture rack fitted with three $60 \mathrm{~W}$ florescent tubes and two $40 \mathrm{~W}$ tungsten bulbs. A constant light intensity of $2400 \pm 40$ lux was maintained and measured using a digital lux meter (Extech Instruments, USA) with triplicates. The physicochemical analysis of domestic sewage water on course bioremediation was done over the period of four weeks. The samples from the BOD bottles were subjected to analysis upto 4 weeks at weekly interval (10). The results are presented as mean \pm SD of triplicates. The various parameters analyzed were subjected to statistical analysis using software SPSS (Version 12.0). Statistical significance was determined by one-way ANOVA, with $p<0.05$ being considered significant.

\section{Results}

\section{Physico-Chemical Characteristics of Domestic Sewage Water (DSW)}

Physico-chemical characteristics of Domestic Sewage Water sample was presented in table 1.

\begin{tabular}{|l|c|c|}
\hline S.No. & Parameters & Domestic Sewage water \\
\hline 1 & $\mathrm{pH}$ & $7.5 \pm 0.1$ \\
\hline 2 & Temperature $\left({ }^{\circ} \mathrm{C}\right)$ & $26 \pm 1$ \\
\hline 3 & $\mathrm{DO}(\mathrm{mg} / \mathrm{L})$ & $16 \pm 0.5$ \\
\hline 4 & $\mathrm{BOD}(\mathrm{mg} / \mathrm{L})$ & $480 \pm 17$ \\
\hline 5 & $\mathrm{COD}(\mathrm{mg} / \mathrm{L})$ & $71 \pm 2$ \\
\hline 6 & $\mathrm{TDS}(\mathrm{mg} / \mathrm{L})$ & $168 \pm 7.3$ \\
\hline 7 & $\mathrm{TSS}(\mathrm{mg} / \mathrm{L})$ & $26.9 \pm 1.1$ \\
\hline 8 & TS $(\mathrm{mg} / \mathrm{L})$ & $194.9 \pm 8.4$ \\
\hline 9 & SULPHATE $(\mathrm{mg} / \mathrm{L})$ & $364 \pm 11.5$ \\
\hline 10 & CHLORIDE $(\mathrm{mg} / \mathrm{L})$ & $512 \pm 16.2$ \\
\hline 11 & APB & $56 \times 10^{2}$ \\
\hline
\end{tabular}

The values are expressed as Mean \pm S.D. of triplicates $(P<0.005)$ 
DSW had higher Physico-chemical characteristics such as total dissolved Solids (TDS), Total Solids (TS), Biological Oxygen Demand (BOD), Chemical Oxygen Demand (COD), chloride and sulphate at par with sewage standard for discharge to the environment. The value of average temperature $\left(\mathrm{T}\right.$ in $\left.{ }^{\circ} \mathrm{C}\right)$ of DSW is $26 \pm 1$. The average value of temperature of sample is found to be slightly high to that of atmospheric temperature observed on the day of sample collection, but it is in permissible limit (BIS). Due to high amount of TDS in the DSW $(168 \pm 7.3 \mathrm{mg} / \mathrm{L})$, the average and values of TS is also showing the high value, $194.9 \pm 8.4 \mathrm{mg} / \mathrm{L}$, respectively. TSS values are also found to be very high $(26.9 \pm 1.1 \mathrm{mg} / \mathrm{L})$. BOD (average $=480 \pm 17 \mathrm{mg} / \mathrm{L}$ ) and COD (average $=71 \pm 2 \mathrm{mg} / \mathrm{L}$ ) values are found to be very high and well above the prescribed limit by BIS, indicating a heavy load of organic compounds in the DSW. The minerals such as sulphate and chlorides are valued as $364 \pm 11.5$ and $512 \pm 16.2 \mathrm{mg} / \mathrm{L}$ respectively.

Effect of Temperature on APB isolates (Growth in Cells/ml)

\begin{tabular}{|c|c|c|c|c|}
\hline S.No. & $\begin{array}{c}\text { Bacterial } \\
\text { Isolates }\end{array}$ & $25^{\circ} \mathrm{C}$ & $30^{\circ} \mathrm{C}$ & $35^{\circ} \mathrm{C}$ \\
\hline 1 & RP1 & $65 \times 102$ & $282 \times 104$ & $75 \times 103$ \\
\hline 2 & RP2 & $56 \times 102$ & $177 \times 105$ & $94 \times 103$ \\
\hline 3 & RP3 & $76 \times 102$ & $135 \times 105$ & $173 \times 103$ \\
\hline
\end{tabular}

\section{Effect of temperature on the isolates}

The effect of temperature on the growth rate of test isolates have shown that range of temp $30^{\circ} \mathrm{C}$ showed a better growth rate compared to $25^{\circ} \mathrm{C}$ and temperature $\left(35^{\circ} \mathrm{C}\right)$ (Table 2). All the three isolates, RP1, RP2 and $\mathrm{RP} 3$ showed better growth at $30^{\circ} \mathrm{C}$ Table Effect of $\mathbf{p H}$ on the isolates

The influence of $\mathrm{pH}$ viz., 5, 6, 7, 8 and 9 on the test isolates with regard to $\mathrm{CFU} / \mathrm{mL}$ was observed. The bacterial isolates RP1 and RP2 showed maximum growth at $\mathrm{pH} 8$ and exhibited the colony forming units ranging from $164 \times 105$ to $256 \times 105$ per $\mathrm{ml}$. On the other hand, the isolate RP3, showed maximum growth at $\mathrm{pH}$ 7 and exhibited the colony forming units in $135 \times 105$ per $\mathrm{mL}$ (Table 3).

Table 3: Effect of pH on APB isolates (Growth in Cells/ml)

\begin{tabular}{|c|c|c|c|c|c|c|}
\hline $\begin{array}{c}\text { S. } \\
\text { No. }\end{array}$ & $\begin{array}{c}\text { Bacterial } \\
\text { Isolates }\end{array}$ & $\mathrm{pH} 5$ & $\mathrm{pH} 6$ & $\mathrm{pH} 7$ & $\mathrm{pH} 8$ & $\mathrm{pH} 9$ \\
\hline 1 & RP1 & $46 \times 102$ & $89 \times 102$ & $282 \times 104$ & $164 \times 105$ & $24.7 \times 103$ \\
\hline 2 & RP2 & $38 \times 102$ & $64 \times 102$ & $177 \times 105$ & $256 \times 105$ & $32 \times 103$ \\
\hline 3 & RP3 & $30 \times 102$ & $69 \times 102$ & $135 \times 105$ & $89 \times 105$ & $52 \times 103$ \\
\hline
\end{tabular}

\section{Bioremediation of Domestic Sewage water by APB isolates}

There are three isolates were found from the sample and coined as RP1, RP2 and RP3. Amongthem, RP1 and RP2 were identified as Citrobacter $s p$. and Rhodopseudomonas sp.

Graph 1

BOD

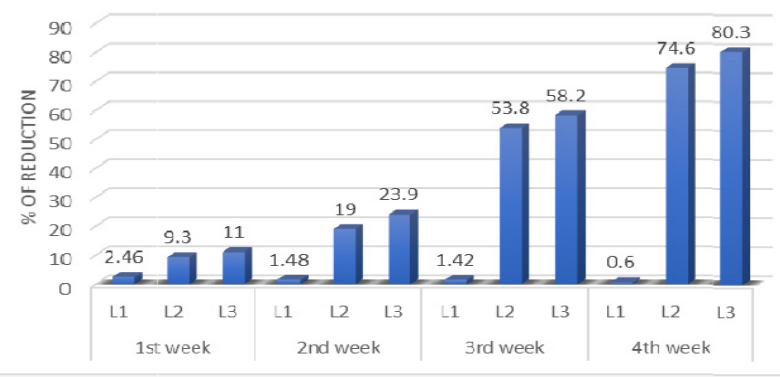

Percentage of COD reduction during Bioremediation

Graph 2

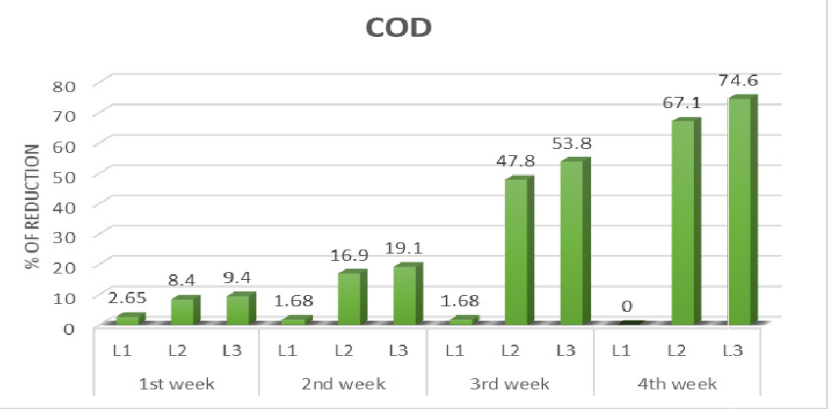

Percentage of TS reduction during Bioremediation

Graph 3

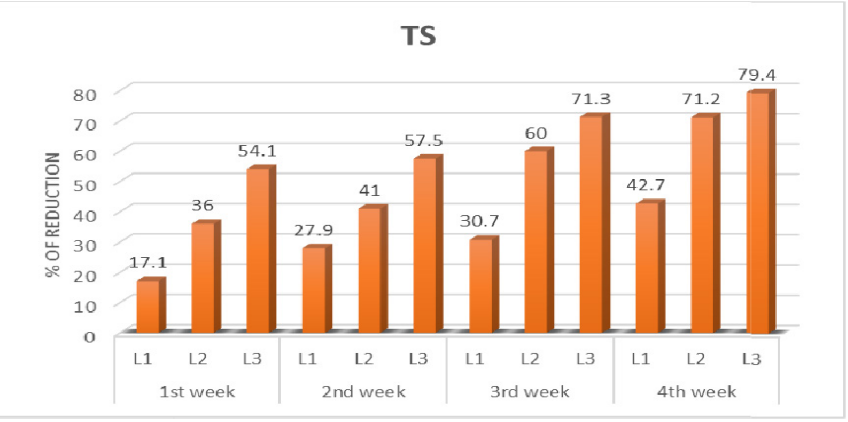

Percentage of Sulphate reduction during Bioremediation Graph 4

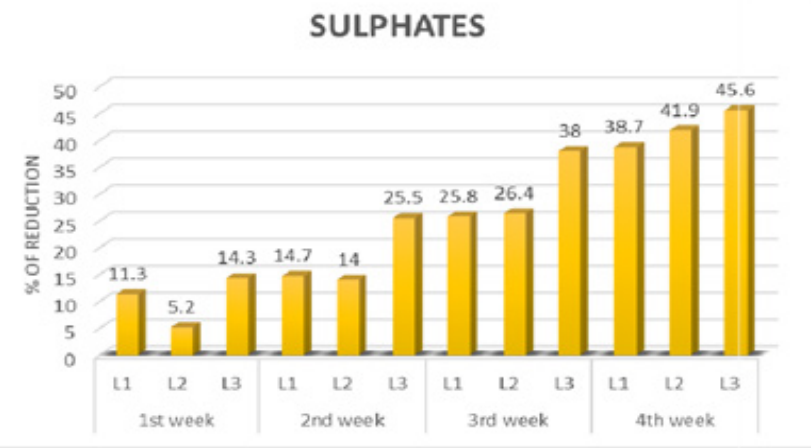

Percentage of Chloride reduction during Bioremediation 


\section{Graph 5}

\section{CHLORIDES}

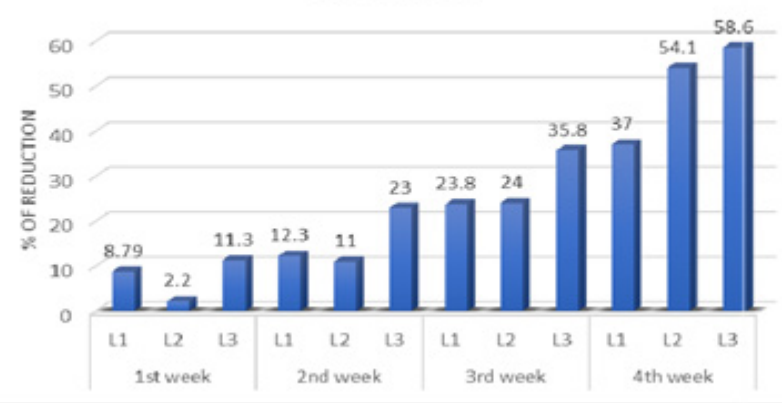

BOD and TSS reduction was maximizing with the isolate RP2 followed by RP1 after 4th week of bioremediation (Fig. $1 \& 2$ and Graph 1-5). The isolate RP2 showed more activity in terms of all the parameters compared to other isolate (RP1). The percentage of BOD and COD reduction achieved after 3rd week of bioremediation to $80.3 \%$ and $74.6 \%$ respectively in L3 lot. But in L2, it was $74.6 \%$ and $67.1 \%$ respectively. In $L 1$, both BOD and COD value was increased. The Coloured wastewater with very high BOD results in eutrophication of contaminated water sources, besides reducing dissolved oxygen in water bodies.

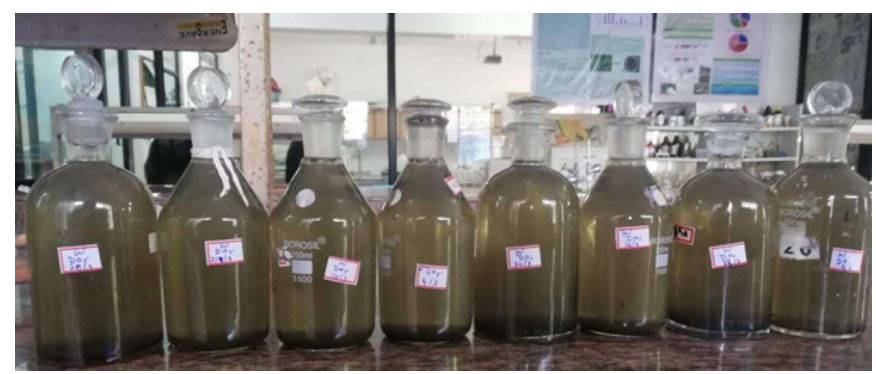

Figure 1. Bioremediation of DSW by APB isolates RP1 and RP2 on day

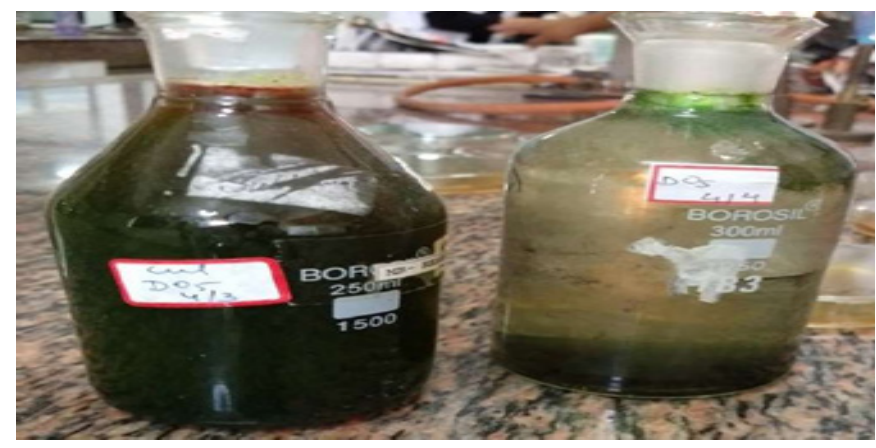

Figure 2. Bioremediation of DSW after 4th week by APB isolates RP2 Discussion

in a developing country like India, domestic sewage water has become a major source of pollution as $70 \%$ of its raw materials are converted into waste and discharged into the water bodies, causing water pollution. In this study, Anoxygenic phototrophic bacterial isolates were subjected to primary screening process to find out bioremediation of domestic sewage water. The average value of $\mathrm{pH}$ of DSW is found to be 7.5 , which is slightly alkaline. It is in permissible level prescribed by BIS (5.59.0). Hence, the $\mathrm{pH}$ of the DSW is within the limitfor discharge of domestic sewage water. TS, TSS and TDS are found to be well above the tolerance limit prescribed by BIS and hence they are to be necessarily removed by bioremediation, before discharge. It has been reported that the enzymes which are essential for the growth and multiplication of microorganisms need the temperature around $30^{\circ} \mathrm{C}(11)$ and that may be the reason for the better growth of test isolates in the present study. Optimum $\mathrm{pH}$ helps to maintain all the nutrients, salts, and water present in a correct proportion which will favor the growth of the organism (12). Pan et al. (13) noticed higher growth rate of the microbial population as well as metabolic activities at neutral redox condition $(\mathrm{pH}$ 8). Operation at $\mathrm{pH} 9$ doesn't support microbial growth as well as metabolic activities. Similar pattern of growth rate was observed at $\mathrm{pH} 6$ might be due to the decreased metabolic activities at acidophilic and basic redox conditions respectively. BOD is a measure of biologically degradable organic matter. Biozlogical processes are most economical for waste treatment and microbial based remediation of waste waters offer an eco-friendly approach to the existing chemical or physical methods. Optimization studies and predicting the performance of various microorganisms for the biodegradation of the organic pollutants is the need of the day. Different environmental factors like $\mathrm{pH}, \mathrm{BOD}$, COD, dissolved oxygen (DO), number and species of microorganism present, nutrient contamination and bioavailability of the contaminants affect biodegradation processes. Treatment of aquarium water by using immobilized phototrophic bacteria by $R$. sphaeroides was investigated. $R$. molischianum was successfully used to treat straw paper mill and sugar refinery water. The practical application of anoxygenic phototrophic bacteria in biological treatment and bioremediation was studied byAtkinson et al. (9) and Wilson et al.(14) The results showed that all the studied bacterial isolates after incubation of 3rd week had maximum biodegradation activity and reduction percentage of both organic and inorganic pollutants in the presence of L3 lot. However, there was less biodegradation activity of the cultures without supplementation in DSW. This confirms that supplements in DSW are providing to do degradation effectively. Once the readily available supplements are exhausted, the rate slows down rapidly. Analysis of the data demonstrated that the characteristics of the DSW are in agreement with the reported values by other researchers (15-16). It also blocks sunlight entry into rivers and streams, thus, reducing oxygenation of water by photosynthesis and hence, is detrimental to aquatic life. Similar finding of bioremediation of domestic sewage water in presence of anaerobic and phototrophicsources was reported by Banerjee et al.(17) and Madigan et al. (18) reported the maximum BOD reduction at $82.5 \%$ by Pseudomonas $s p$. at $35^{\circ} \mathrm{C}$ under anaerobic conditions in the presence of either peptone or yeast extract as 
supplemental nutrient. When pollutants were monitored as a function of time, it was observed that there was an increase in \% reduction with time(19-20) Similarly, in the present work, maximum degradation of organic and inorganic pollutants was achieved by 3 rd week of treatment in the presence of RP2 (Rhodopseudomonas $s p$.). Thus, the present investigation adds some additional information for effective management of domestic sewage water through bioremediation by indigenous Anoxygenic phototrophic bacteria isolates (especially RP2 Rhodopseudomonas sp.). It also throws light on the bio remediating potential of indigenous Anoxygenic phototrophic bacteria on domestic sewage water; thus, paving way for future research.

\section{Acknowledgements}

We gratefully acknowledge the Indian Academy Degree College Autonomous for the kind support to carry out the research.

\section{Conflict of Interest}

All authors developed the theory and investigate of this work. And also authors discussed the results and contributed to the final manuscript. Authors have declared that no conflicting interests exist.

\section{References}

1. Zhao, J., Wang, D., Li, X., Yang, Q., Chen, H., Zhong, Y., An, H., \&Zeng, G. (2015). An efficient process for wastewater treatment to mitigate free nitrous acid generation and its inhibition on biological phosphorus removal. Scientific Reports, 5(1), 158245. https://doi.org/10.1038/srep08602

2. Liu, Z.-, Kanjo, Y., \&Mizutani, S. (2009). Removal mechanisms for endocrine disrupting compounds (EDCs) in wastewater treatment physical means, biodegradation, and chemical advanced oxidation: A review. Science of The Total Environment, 407(2), 731-748. https://doi. org/10.1016/j.scitotenv.2008.08.039

3. Kosamu, I. B. M., \&Obst, M. (2009). The influence of picocyanobacterial photosynthesis on calcite precipitation. International Journal of Environmental Science \& Technology, 6(4), 557-562. https://doi. org/10.1007/bf03326095

4. Zhang, X. X., Zhao, D. Y., Wang, Z. X., Wu, B., Li, W. X., \& Cheng, S. P. (2008). Environmental biological model based on optimization of activated sludge process. International Journal of Environmental Science \& Technology, 6(1), 69-76. https://doi. org/10.1007/bf03326061

5. Madukasi, E. I., Dai, X., He, C., \& Zhou, J. (2009). Potentials of phototrophic bacteria in treating pharmaceutical wastewater. International Journal of Environmental Science \& Technology, 7(1), 165174. https://doi.org/10.1007/bf03326128

6. Walter, W. G. (1995). STANDARD METHODS FOR THE EXAMINATION OF WATER AND WASTEWATER (19th ed.). American Journal of Public Health and the Nations Health, 51(6), 940. https://doi.org/10.2105/ajph.51.6.940-a

7. Archana, A., Sasikala, C., Ramana, C. V., \&Arunasri, K. (2004). "Paraffin wax-overlay of pour plate", a method for the isolation and enumeration of purple non-sulfur bacteria. Journal of Microbiological Methods, 59(3), 423-425. https://doi.org/10.1016/j. mimet.2004.08.006

8. Imhoff J.F. (2006) The Phototrophic AlphaProteobacteria. In: Dworkin M., Falkow S., Rosenberg E., Schleifer KH., Stackebrandt E. (eds) The Prokaryotes. Springer, New York, NY. https://doi.org/10.1007/0-387-30745-1_2

9. Coliform and Escherichia coli from biological effluents. Scientific Reports, 5(1), 51-63. https://doi. org/10.1038/srep09461

10. Vijayaraghavan, K., Ahmad, D., \& Ezani Bin Abdul Aziz, M. (2007). Aerobic treatment of palm oil mill effluent. Journal of Environmental Management, 82(1), 24- 31. https://doi.org/10.1016/j. jenvman.2005.11.016

11. Zhu, A., Guo, J., Ni, B.-J., Wang, S., Yang, Q., \&Peng, Y. (2015). A Novel Protocol for Model Calibration in Biological Wastewater Treatment. Scientific Reports, 5(1), 84-93. https://doi. org/10.1038/srep08493

12. Symonds, E. M., Cook, M. M., McQuaig, S. M., Ulrich, R. M., Schenck, R. O., Lukasik, J. O., Van Vleet, E. S., \&Breitbart, M. (2015). Reduction of nutrients, microbes and personal care products in domestic wastewater by a benchtop electrocoagulationunit. Scientific Reports, 5(1), 83-90. https://doi. org/10.1038/srep09380

13. Pan, B., Zhang, Q., Du, W., Zhang, W., Pan, B., Zhang, Q., Xu, Z., \& Zhang, Q. (2007). Selective heavy metals removal from waters by amorphous zirconium phosphate: Behavior and mechanism. Water Research, 41(14), 3103-3111. https://doi. org/10.1016/j.watres.2007.03.004

14. Wilson, S. M., Gleisten, M. P., \& Donohue, T. J. (2008). Identification of proteins involved in formaldehyde metabolism by Rhodobacter sphaeroides. Microbiology,154(1), 296-305. https:// doi.org/10.1099/mic.0.2007/011346-0 
15. Pol, L. H., \&Lettinga, G. (1986). New Technologies for Anaerobic Wastewater Treatment. Water Science and Technology, 18(12), 41-53. https://doi. org/10.2166/wst.1986.0162

16. Choorit, W., Thanakoset, P., Thongpradistha, J., Sasaki, K., \&Noparatnaraporn, N. (2002). Identificationand cultivation of photosyntheticbacteria in wastewater from a concentrated latex processing factory. Biotechnology Letters, 24(13), 1055-1058. https://doi.org/10.1023/a:1016026412361

17. Banerjee, S., Azad, S. A., Vikineswary, S., Selvaraj, O. S., \& Mukherjee, T. K. (2000). Phototrophic Bacteria as Fish Feed Supplement. AsianAustralasian Journal of Animal Sciences, 13(7), 991-994. https://doi.org/10.5713/ajas.2000.991

18. Madigan,M.T.,Jung, D.O.,Woese,C.R., \&Achenbach, L. A. (2000). Erratum to Rhodoferaxantarcticus sp. nov., a moderately psychrophilic purple nonsulfur bacterium isolated from an Antarctic microbial mat. Archives of Microbiology, 173(5-6), 449. https://doi. org/10.1007/s002030000168

19. Yang, Y., Wang, P., Shi, S., \& Liu, Y. (2009). Microwave enhanced Fenton-like process for the treatment of high concentration pharmaceutical wastewater. Journal of Hazardous Materials, 168(1), 238-245. https://doi.org/10.1016/j.jhazmat.2009.02.038

20. Mukkata, K., Kantachote, D., Wittayaweerasak, B., Techkarnjanaruk, S., \&Boonapatcharoen, N. (2016). Diversity of purple nonsulfur bacteria in shrimp ponds with varying mercury levels. Saudi Journal of Biological Sciences, 23(4), 478-487. https:// doi.org/10.1016/j.sjbs.2015.05.014Percentage of Chloride reduction during Bioremediation 